Marquette University

e-Publications@Marquette

$1-1-2008$

\title{
The Community of Nursing: Moral Friends, Moral Strangers, Moral Family
}

Carolyn A. Laabs

Marquette University

This is the peer reviewed version of an article that appeared in Nursing Philosophy: The Official Journal of the International Philosophy of Nursing Society, Vol. 9 No. 4 (2008). Published in final form here: DOI. This article may be used for non-commercial purposes in accordance With Wiley Terms and Conditions for self-archiving. (C) 2008 John Wiley \& Sons, Inc. Used with permission. 
NOT THE PUBLISHED VERSION; this is the author's final, peer-reviewed manuscript. The published version may be accessed by following the link in the citation at the bottom of the page.

\title{
The Community of Nursing: Moral Friends, Moral Strangers, Moral Family
}

\author{
Carolyn A. Laabs \\ College of Nursing, Marquette University \\ Milwaukee, WI
}

\begin{abstract}
Unlike bioethicists who contend that there is a morality common to all, H. Tristan Engelhardt (1996) argues that, in a pluralistic secular society, any morality that does exist is loosely connected, lacks substantive moral content, is based on the principle of permission and, thus, is a morality between moral strangers. This, says Engelhardt, stands in contrast to a substance-full morality that exists between moral friends, a morality in which moral content is based on shared beliefs and values and exists in communities that tend to be closely knit and religiously based. Of what value does Engelhardt's description of ethics as moral friends and moral strangers have for nursing? In this essay, I attempt to show how Engelhardt's description serves to illustrate how the nursing community historically had been one of moral friends but has gradually become one of moral strangers and, hence, at risk of failing to protect patients in their vulnerability and of compromising the integrity of nursing. Building on Engelhardt's concepts, I suggest we might consider modern nursing like a moral family to the extent that members might at times relate to one another as moral strangers but still possess a desire and a need to reconnect with the common thread that
\end{abstract}


binds us as moral friends. Nursing is a practice discipline. Given the challenges of modern bioethics, an applied ethic is needed to give moral direction to clinicians as we strive to conduct ourselves ethically in the practice of our profession. To that end, nursing should reflect upon and seek to reconnect with the content-full morality that is historically and religiously based.

The family. We were a strange little band of characters trudging through life sharing diseases and toothpaste, coveting one another's desserts, hiding shampoo, borrowing money, locking each other out of our rooms, inflicting pain and kissing to heal it in the same instant, loving, laughing, defending, and trying to figure out the common thread that bound us all together (Bombeck, n.d.).

Our society is a secular one characterized by a plurality of persons having a variety of moral perspectives and differing views on the moral threads that bind us. Beauchamp \& Childress (2001, p. 143), whose famous four principles have dominated biomedical ethics, insist that, despite our differences, a morality exists that is common to all morally serious persons, in which the moral justification of an action lies in it being validly authorized by another person. Gert et al. (2006) concur that a common morality exists, but that it is based on the widespread agreement among people on moral matters. However, Engelhardt (1996) contends that, in a pluralistic secular society such as ours, there is no common morality. Any morality that does exist is between 'moral strangers' and, thus, is based on the 'principle of permission' and lacks substantive moral content. Unlike the substance-less morality of moral strangers, Engelhardt insists that there is also a substance-full morality that exists between 'moral friends', a morality filled with moral content that is based on shared beliefs and values. In addition, moral friends exist in communities that tend to be closely knit and religiously based, as opposed to the loose secular connections of moral strangers associated by permission, authorization or agreement. Engelhardt offers a descriptive ethic about society, rather than a normative one, and maintains that this description should not be considered an applied ethic. However, in a practice discipline such as nursing, an applied ethic is precisely what is needed to give moral direction to clinicians as they strive to conduct themselves ethically in the practice of their 
profession. Of what value does Engelhardt's description of ethics as moral friends and moral strangers have for nursing?

In this essay, I will attempt to show how Engelhardt's (1996) description is useful to nursing because it serves to illustrate how the nursing community has historically been one of moral friends but has become one of moral strangers and, hence, at risk of failing to protect patients in their vulnerability and of compromising the integrity of nursing. I suggest that one way of reducing this risk, rather than conceptualize nursing as a moral community, is to consider it more like a moral family, one that is in need of reconnecting with the common thread that binds members as moral friends. I will begin by defining the concepts of moral friends and moral strangers, as explained by Engelhardt. I will then describe the status of the nursing profession today, provide a brief historical background of nursing, propose how nursing might be like a moral family, and suggest why striving to be more like a moral family might be important to the nursing profession.

\section{Moral strangers and moral friends}

Secular society is characterized by differing moral visions and notions of what counts as moral obligations, rights and values. Each account of morality asserts itself as the one deserving priority status, and, given the limits of secular moral reasoning, it is, therefore, impossible to discover a single ethic for all. Engelhardt (1996, p. 7) refers to this situation as one of being 'moral strangers'-'persons who do not share sufficient moral premises or rules of evidence and inference to resolve moral controversies by sound rational argument, or who do not have a common commitment to individuals or institutions in authority to resolve moral controversies'. Secular moral reasoning is limited, as Engelhardt sees it, in that it lacks a 'canonical, content-full' ethic for bioethics to apply to real-life situations. A content-full morality provides substantive guidance regarding what is right or wrong, good or bad, beyond merely requiring that persons not use others without their permission. From this content-full morality, concrete communities emerge within which people can live coherent moral lives and pursue virtue because they are able to give full and substantial content to the moral life (Engelhardt, p. viii). These communities are often associated with religions, but they can also be communities with no religious affiliation. In contrast to moral 
strangers, Engelhardt (p. 7) refers to members of these communities as 'moral friends'-'those who share enough of a content-full morality so that they can resolve moral controversies by sound moral argument or by an appeal to a jointly recognized moral authority whose jurisdiction they acknowledge as derived from a source other than common agreement'. Truth is known by moral friends and can be discovered in the particular moral narratives that are shared by moral friends but are neither comprehended nor appreciated by moral strangers.

Although it is possible for moral strangers to become moral friends, Engelhardt (1996) does not believe that this is likely to happen on a widespread basis in a society pervaded by secularism and priding itself on individual freedom. If one is to bridge diverse moral divides, Engelhardt (p. xi) contends that bioethics must settle for an ethic governed by the principle of permission, a principle that recognizes secular moral authority as derived from the permission of the persons involved in the common undertaking. In this line of thinking, authority does not come from God, or a particular community's moral vision, nor does it come from reason, but instead from the permission granted to one individual by another individual. As a result, individuals remain moral strangers and do not become moral friends. This stalemate in moral progress Engelhardt attributes to the failure of the Enlightenment to provide a canonical, concrete morality that can bind all and provide a concrete moral vision for all.

\section{The nursing community today}

Modern nursing reflects the make-up of society, and, thus, nursing is characterized by pluralism and secularism. What makes nursing a community is the fact that it is a profession having shared values and goals among its members. According to the American Association of Colleges of Nursing (1998) caring is the concept central to the practice of professional nursing, and the values that epitomize the caring nurse are altruism, autonomy, human dignity, integrity and social justice. The American Association of Colleges of Nursing acknowledges that the concept of caring and the five core values are vaguely defined and applied in a variety of ways among nurses, and, hence, educational efforts and socialization of nurses at least should attempt to make nurses aware of social and ethical issues

[Nursing Philosophy: The Official Journal of the International Philosophy of Nursing Society, Vol 9, No. 4 (October 2008 ): pg. 225-232. DOI. This article is @ Wiley and permission has been granted for this version to appear in e- 
and of their own value systems, but cannot be expected to do much more than that.

Nursing is the largest healthcare occupation in the United States (United States Department of Labor Bureau of Labor Statistics, 2007) and worldwide (International Council of Nurses, 2008a). The American Nurses Association (2008a) defines nursing as 'the protection, promotion, and optimization of health and abilities, prevention of illness and injury, alleviation of suffering through the diagnosis and treatment of human response, and advocacy in the care of individuals, families, communities, and populations'. Nurses in the United States function under a code of ethics that was composed by a task force of the American Nurses Association and considered 'a general guide for the profession's members and . . . a social contract with the public that it serves . . . that reflects our fundamental values and ideals as individual nurses and as a member of a professional group' (Fowler, 2008, p. xi). The International Council of Nurses (2008b) offers a definition of nursing similar to, but broader than, that of the American Nurses Association:

Nursing encompasses autonomous and collaborative care of individuals of all ages, families, groups and communities, sick or well and in all settings. Nursing includes the promotion of health, prevention of illness, and the care of ill, disabled and dying people. Advocacy, promotion of a safe environment, research, participation in shaping health policy and in patient and health systems management, and education are also key nursing roles.

The International Council of Nurses (2006, p. 4) also has a code of ethics for nurses formulated by a committee and said to be 'a guide to action based on social values and needs . . . [having] meaning only as a living document [when] applied to the realities of nursing and health care in a changing society'. These definitions of nursing are broad, vague and not religiously based, and the codes of ethics are referred to as action guidelines that change with changing realities and, hence, relative to the situation. Thus, the nursing community today clearly has a secular orientation and, according to Engelhardt's theory, would lack a sufficient content-full morality that would enable moral controversies to be resolved by sound reasoning. 
The moral authority in nursing comes from agreement among committees and task forces. Therefore, using Engelhardt's criteria, nursing today cannot be considered a community of moral friends but instead a group of moral strangers guided by agreement or consensus. However, this has not always been the case for nursing. A glimpse at nursing's past may provide insight into nursing's present and guidance for its future.

\section{A bit of nursing history}

Goodnow (1939, pp. 24-25) referred to nursing as 'the great, universal mother-instinct' that has attended to the needs of the helpless since the times of primitive peoples. In this primitive and instinctive care of the sick, there had been no distinction between nursing and medicine (Goodnow, 1939; Donahue, 1996). Even today, disagreement continues as to which activities are nursing and which belong to medicine, yet there is a growing recognition that, while some activities are uniquely medicine or uniquely nursing, some are shared or overlap.

During primitive times, for both nursing and medicine, disease often appeared mysterious, and, hence, supernatural forces frequently were seen as the cause and the means of cure. Thus, the medicine man, or shaman, for example, was called upon to help the sick, and, as a result, religion and medicine became inextricably linked. Although some of the mystery of illness has been unveiled by modern science, a certain degree of mystery remains today, and cures are still sometimes attributed to the miraculous.

The religious aspect of medicine was greatly strengthened with the coming of Christ and his emphasis on charity (Donahue, 1996) and altruism (Goodnow, 1939). The introduction of charity and altruism into a world of disinterested service to humanity profoundly affected nursing. According to Goodnow (p. 35), altruism is the motive that has elevated nursing to a place among the professions, and it was the early Christian Church, following in the example of Christ, that took upon itself the care of the helpless and the sick. This philosophy continued into the 20th century as Harmer (1925, p. 3) describes the object and ideals of nursing in terms of service and ministry to a suffering humanity:

[Nursing Philosophy: The Official Journal of the International Philosophy of Nursing Society, Vol 9, No. 4 (October 2008 ): pg. 225-232. DOI. This article is (C) Wiley and permission has been granted for this version to appear in e- 
Nursing is rooted in the needs of humanity and is founded on the ideal of service. Its object is not only to cure the sick and heal the wounded but to bring health and ease, rest and comfort to mind and body, to shelter, nourish, and protect and to minister to all those who are helpless or handicapped, young, aged or immature.

Nightingale (1914, p. 146), commonly referred to as the founder of modern professional nursing, had an acute awareness of the sacred in the work of nursing when she referred to it as 'the high calling of God in Christ Jesus', and asked, 'What higher calling can we have than Nursing?' Nightingale went on to say that '. . . the highest 'authority' which a woman especially can attain among her fellow women must come from her doing God's work here in the same spirit, and with the same thoroughness, that Christ did'.

This is not to say that charity and altruism are limited to Christianity, nor it is to imply that nursing should be restricted to women. Certainly other religions and even individuals who do not believe in God are capable of works of charity and altruism, although atheism, unlike Christianity and other religions, does not oblige such works of their followers. Similarly, Goodnow's (1939) reference to nursing as a 'mother-instinct' and Nightingale's (1914) comments in terms of women should not be interpreted to mean that men should be excluded from the nursing profession. On the contrary, throughout most of human history, nursing care has been provided by men, beginning with the world's first nursing school which opened in India centuries before the Christian era, where nursing was restricted to men of Brahmin or priestly orders, and extending to include the many military, religious, and lay orders of men dedicated to providing nursing care during the middle ages (Dock \& Stewart, 1938), and some of these orders, such as the Order of Saint Camillus Servants of the Sick, continue today.

What this history suggests is that nursing is rooted in human values that are religiously based. Nursing's morality can be traced to a history and tradition that are not entirely secular, but rather possess a theological dimension from which human beings recognize the need for divine guidance on their common journey. According to Engelhardt's theory, this is the substance required of a 'content-full morality' that 
can give moral direction to clinicians as they apply scientific theory and practical knowledge to the care of the sick.

\section{Nursing as moral family}

In this essay the word 'family' does not refer to the traditional family in terms of marriage, mother, father and their children. It is conceptualized more broadly, and the following common definition is used: 'a group of people united by certain convictions or a common affiliation, related by common characteristics; a basic unit in society that fosters the enculturation, socialization, and growth of younger members' (Merriam-Webster Online, 2008). Understood this way, the nursing profession could be considered like a family.

Within a family, sometimes individual members get along with one another, agree and consider each other friends, while sometimes they do not, even to the point of estrangement. Despite these differences, individuals remain members of the family and continue to have an allegiance to the family, at some level. Even when estranged, one's deep seated hope, albeit sometimes unrecognized, is to eventually achieve or regain friendship within the family. Often it is at times of crisis or significant need when reunions and reconciliations occur within a family. It is during these times that the retelling and reflecting on the stories of shared experiences, family history and traditions serve to help family members recall and reconnect with what binds them as family. These times often centre on issues of life and death, celebrations of the beginning of life, and memorials of lives that have come to an end. Much of the work of nursing centres on issues of life and death, the beginning of life and the end of life, as well as the many aspects of life that arise between them.

Just as family members disagree, so do members of the nursing profession. Not all nurses agree on issues related to nursing, and some are at complete odds with one another. Consider the long-standing disagreement about the appropriate level of entry into professional practice. Is having a diploma or an associate degree sufficient to qualify as a registered nurse, or must all registered nurses be required to have a baccalaureate degree? While that disagreement continues to simmer, a new disagreement has arisen to a boil recently regarding entry into advanced practice. Is a master's degree sufficient for 
registered nurses to qualify as advanced practice nurses, or should a doctor of nursing practice degree be required of all advanced practice nurses? Another dispute strikes at the heart of nursing, 'what it is and what it is not' (Nightingale, 1859). Has nursing become too much like medical practice? This is a contentious issue for advanced practice nurses as their role continues to evolve. Furthermore, the American Nurses Association (2008b, 2008c), said to be the only full-service professional organization representing registered nurses in the United States, takes positions on controversial social and ethical issues that are not shared by all nurses, such as support of abortion rights, support of human embryonic stem cell research, opposition to nurse participation in capital punishment, and the endorsement of political candidates. Regarding national nurses' codes of ethics, studies find disagreement among nurses as to their purpose, function, content and practical value, and that nurses tend to rely instead on personal values and experiences when considering moral dimensions of practice (Tad et al. 2006). Some specialty areas of nursing, such as nurse midwifery (American College of Nurse-Midwives, 2005) and nurse anaesthetists (American Academy of Nurse Anesthetists, 2008), have their own code of ethics, and there has been discussion among nurse practitioners that they should draft a code of their own as well (Peterson \& Potter, 2004).

With all this disagreement nursing would easily seem to meet Engelhardt's criteria for moral strangers. However, despite the seeming irreconcilability, there is a fundamental ethos that binds nursing as moral friends. This ethos can be found in the mythos of nursing, the stories of the history and traditions of nursing. A mythos consists of the narratives that are considered 'sacred word' and, thus, traditional and authoritative. As Sulmasy (1999, p. 231) argues, 'Every ethos implies a mythos', which is to say that all ethical discourse depends upon mythic narratives that provide a set of starting premises or background of beliefs needed to justify the system of ethics:

Inescapably, every system of normative ethics requires a commitment of faith in some conception of what it means to be human, some conception of the good, a view about the meaning of human suffering, some view about human freedom, a view about the relationship between body and person (or body and 
soul), and a view about the proper relationship between individual human beings and their human communities. None of this comes from logic. It is the stuff of mythology . . . Morality follows from these starting points ... What can be abstracted from these fundamental myths as premises and then logically deduced is only part of morality. The myths continue to inform and to shape and to put flesh upon logical conclusions . . . It is always reason that begins with myth and is shaped by myth.

Nursing's conception of the good, what it means to be human, the meaning of human freedom and human suffering, and the relationship between individual human beings and their human communities is derived from the 'stuff' of the stories of the history and traditions in nursing.

According to Engelhardt (1996, p. 7), community is 'a body of men and women bound together by common moral traditions and/or practices around a shared vision of the good life, which allows them to collaborate as moral friends'. Therefore, even though nursing may be dominated by the secularism of moral strangers, it could still be a community because of the potential to be moral friends. In fact, because of the intimate nature of the work nurses do, i.e. sharing profoundly in the human responses to life and death experiences of patients, nurses are more than just community but a family having a deep-seated desire to free themselves of the bonds of estrangement, and open the doors to discovering and appreciating the common thread that binds them as moral friends. This can be done by nurses recollecting and reflecting on the mythos of nursing, reconnecting with nursing's religiously based roots and rekindling the ethos that is full of content and gives direction to the profound moral work that nurses are called to do.

\section{Must we be friends?}

Is there a problem with being moral strangers? So what if nurses are not moral friends? What is the harm in that? Health care is an industry and one does not need to be moral friends to successfully conduct the business of health care.

While it is true that modern health care has become a business, the experience of illness, on a human level, has not because it simply can not. Illness, injury and infirmity are more than biological,

[Nursing Philosophy: The Official Journal of the International Philosophy of Nursing Society, Vol 9, No. 4 (October 2008 ): pg. 225-232. DOI. This article is (C) Wiley and permission has been granted for this version to appear in e- 
psychological or social experiences. They are also spiritual ones that remind us of the uncomfortable and inescapable reality of our human frailty and finitude. Nursing, by its nature, is a moral endeavour that attends to the human responses to these complex experiences and, thus, requires a morality beyond mere permission or simple agreement. It requires a morality that has the depth and fullness of the truth and knowledge of the good. Anything less could place patients at risk that the nurse may not respond to their vulnerability in a way that is consistent with their patient's intrinsic dignity and inestimable worth. It also places nurses at risk that their responses may not be consistent with the dignity inherent to them and the integrity demanded of them as individuals and also by the profession and its ethos properly understood.

'Moral friends are those persons who share enough of a contentfull morality so that they can resolve moral controversies by sound moral argument or by an appeal to a jointly recognized moral authority whose jurisdiction they acknowledge as derived from a source other than common agreement' (Engelhardt 1996, p. 7). Moral strangers do not share enough of a moral vision to enable them to discover content-full resolutions to their moral controversies. Nevertheless, like members of a family, nurses must respect and tolerate the deeply held convictions of other nurses, even if they believe some of the convictions are misguided. However, toleration does not equate with silence when others act in ways that are incompatible with the history and traditions of nursing and, thus, violate the content-full morality that characterizes the profession. In these situations nurses, like families, need to recollect and reflect on the stories and experiences shared by members of the profession and reconnect with the content-full morality that can be found in the history and traditions that are religiously based.

\section{Conclusion}

The theoretical, practical and moral aspects of nursing are like the head, hands and heart of the profession. Neglect or overemphasis of any one of these can cause an imbalance in the care we provide to our patients (Engelhardt, 1996, p. 7). To reduce the moral aspects of nursing to a secular matter based solely on permission, authorization or consensus is to strip nursing of its religiously based 
roots, wounding it at its heart, and leaving patients at risk of compromised dignity and nursing at risk of compromised integrity. Like families whose members can sometimes be moral strangers but who still seek to find the common thread that binds them, nursing must seek to reconnect with the religiously based morality that binds us as moral friends for the sake of the profession and the patients we serve. Modern nursing would do well to reflect on the words of Nightingale (1914, p. 148) in her address to nurses of the Nightingale School at St. Thomas's Hospital, like a matriarch imparting words of wisdom to her family:

When a Patient, especially a child sees us acting as if there were no God, then there but too often becomes no God to him. Then words become to such a child mere words . . . [thus] I must have moral influence over my Patients. And I can only have this by being what I appear. . . . My patients are watching me. They know what my profession, my calling is: to devote myself to the good of the sick. They are asking themselves: does that Nurse act up to her profession?

Ancillary

\section{References}

American Academy of Nurse Anesthetists (2008) Code of Ethics for the Certified Registered Nurse Anesthetists. Available

at: http://www.aana.com/[accessed 29 April 2008.

American Association of Colleges of Nursing (1998) The Essentials of Baccalaureate Education for Professional Nursing Practice.

Available

at: http://www.aacnhe.edu/Education/pdf/BaccEssentials98.pdf[ accessed. 4 May 2008.

American College of Nurse-Midwives (2005) Standard Setting

Documents. Available

at: http://www.acnm.org/code_of_ethics.cfm[accessed 29 April 2008.

American Nurses Association (2008a) What is nursing? Available

at: http://nursingworld.org/EspecillyForYou/StudentNurses/Wha tisNursing.aspx[accessed 27 April 2008.

American Nurses Association (2008b) About ANA. Available

at: http://nursingworld.org/FunctionalMenuCategories/AboutAN

A.aspx[accessed 4 May 2008.

[Nursing Philosophy: The Official Journal of the International Philosophy of Nursing Society, Vol 9, No. 4 (October 2008 ): pg. 225-232. DOI. This article is (C) Wiley and permission has been granted for this version to appear in e- 
American Nurses Association (2008c) Position Statements. Available at: http://nursingworld.org/MainMenuCategories/Healthcareand PolicyIssues/ANAPositionStatements.aspx[accessed 29 April 2008.

Beauchamp T.L. \& Childress J.F. (2001) Principles of Biomedical Ethics, 5th edn. Oxford University, New York.

Bombeck E. (n.d.) Quotations About Family. Available at: http://www.quotegarden.com/family.html[accessed 4 May 2008.

Dock L.L. \& Stewart I.M. (1938) A Short History of Nursing, 4th edn. G.P. Putman's Sons, New York.

Donahue M.P. (1996) Nursing: The Finest Art an Illustrated History, 2nd edn. Mosby, St. Louis.

Engelhardt H.T. (1996) The Foundations of Bioethics, 2nd edn. Oxford University, New York.

Fowler M. Ed. (2008) Guide to the Code of Ethics for Nurses: Interpretation \& Application. American Nurses Association, Silver Spring, MD.

Gert B., Culver C.M. \& Clouser D. (2006) Bioethics: A Systematic Approach. 2nd edn. Oxford University, New York.

Goodnow M. (1939) Outlines of Nursing History, 6th edn. W.B. Saunders, Philadelphia, PA.

Harmer B. (1925) Text-book of the Principles and Practice of Nursing. The MacMillan Company, New York.

International Council of Nurses (2006) The ICN Code of Ethics for Nurses. Available at: http://www.icn.ch/bookshop.htm[accessed 9 May 2008.

International Council of Nurses (2008a) About ICN. Available at: http://www.icn.ch/abouticn.htm[accessed 27 April 2008. International Council of Nurses (2008b) The ICN Definition of Nursing. Available at: http://www.icn.ch/definition.htm[accessed 27 April 2008.

Merriam-Webster Online (2008) Family. Available at: http://www.merriamwebster,com/dictionary/family[accessed 4 May 2008.

Nightingale F. (1859) Notes on Nursing: What it is and What it is Not. J.B. Lippincott, Philadelphia. 
NOT THE PUBLISHED VERSION; this is the author's final, peer-reviewed manuscript. The published version may be accessed by following the link in the citation at the bottom of the page.

Nightingale F. (1914) The nurse's profession. In: On Moral

Medicine (eds S.Lammers \& A.Verhey), 2nd edn, pp. 146-148. William B. Eerdman, Grand Rapids, MI.

Peterson M. \& Potter R.L. (2004) A proposal for a code of ethics for nurse practitioners. Journal of the American Academy of Nurse Practitioners, 16(3), 116-124.

Sulmasy D.P. (1999) Every ethos implies a mythos: faith and bioethics. In: Notes From a Narrow Ridge: Religion and Bioethics (eds D.Davis \& L.Zoloth), pp. 227-246. University Publishing Group, Hagerstown, MD.

Tad W., Clarke A., Lloyd L. et al. (2006) The value of nurses' codes: European nurses' views. Nursing Ethics, 13(4), 376-393.

United States Department of Labor Bureau of Labor Statistics (2007) Occupational Outlook Handbook, Registered Nurses. Available at: http://www.bls.gov/oco/ocos083.htm[accessed 25 April 2008. 